\title{
Rancang Bangun Sistem Informasi Peminjaman dan Pengembalian Buku Perpustakaan SMP Negeri 1 Madiun
}

\author{
Andi Rahman Putera ${ }^{1}$ dan Malik Ibrahim² \\ ${ }^{1,2}$ Program Studi S1 Informatika, Universitas PGRI Madiun \\ Jl. Auri No 14-16 Madiun Telp(0351) 496128 \\ 'andirahmanputeran@gmail.com; iqbal.ibrahim17@gmail.com
}

\begin{abstract}
ABSTRAK
Pelayanan pendidikan yang paling menonjol di SMP ini adalah perpustakaan. Akan tetapi sistem informasi yang berjalan di perpustakaan ini masih menggunakan tulisan tangan. Dalam meningkatkan proses perkembangannya itulah maka dibangun sistem informasi pepustakaan menggunakan bahasa pemrograman PHP dan MySQL. Model yang digunakan adalah berbasis desktop. Tujuan yang ingin dicapai dari pembangunan sistem informasi perpustakaan ini adalah memperkenalkan agar layanan peminjaman buku kepada siswa dapat dilakukan dengan baik tanpa ada manipulasi data. Hasil yang diinginkan dari pembangunan sistem informasi ini adalah mempermudah siswa dalam meminjam dan mengembalikan buku dan petugas perpustakaan menjadi lebih mudah dan nyaman dalam pengolahan data sehingga perpustakaan SMPN 1 Madiun menjadi lebih maju di bandingkan SMP-SMP lainnya .

Kata Kunci : Sistem Informasi, Perpustakaan, Data Manual
\end{abstract}

\section{PENDA HULUAN}

Perpustakaan adalah suatu lembaga pedidikan di sekolah. Fungsi Perpustakaan sekolah sebagai tempat baca yang sekarang semakin kurang diminati oleh siswa untuk membaca buku. Hal ini desebabkan karena terkalahkan oleh media informasi seperti internet yang lebih mudah digunakan dalam pencarian berbagai macam ilmu dan sumber bacaan. Dampak media informasi tersebut juga dialami oleh perpustakaan SMP Negeri 1 Madiun yang banyak memiliki koleksi buku yang seharusya bisa digunakan oleh para siswa untuk menunjang kegiatan belajar namun siswa kurang tertarik untuk membaca dan meminjam buku dari perpustakaan tersebut selain ada tugas tertentu dari guru yang mengharuskan siswa meminjam buku dari perpustakaan.

Adanya masalah tersebut, maka diperlukan solusi bagaimana cara merancang sistem informasi berbasis desktop yang dapat membantu dalam pengolahan data perpustakaan SMP N 1 Madiun.

Batasan masalah pada penelitian ini adalah melakukan penelitian di SMP $\mathrm{N} 1$ Madiun. sistem informasi yang dibangun mengenai sistem peminjaman, pengembalian, data anggota, data status buku, kode buku, denda keterlambatan dan informasi koleksi buku.

Tujuan penelitian ini adalah untuk merancang dan membangun sistem informasi berbasis desktop yang dapat membantu dalam pengolahan data perpustakaan SMP N 1 Madiun.

Manfaat dari sistem informasi komputer pada perpustakaan SMP Negeri 1 Madiun dapat membantu petugas dalam mengelola administrasi data perpustakaan. Adanya sistem informasi perpustakaan dapat membantu siswa dalam mencari dan melihat koleksi buku

\section{TINJAUAN PUSTAKA}

Dalam merancang sistem informasi peminjaman dan pengembalian buku di perpustakaan SMP N 1 Madiun ini perancang mencari referensi 3 jurnal:

1. Pembuatan Sistem Informasi Perpustakaan Berbasis Website Pada Sekolah Menegah Pertama Negeri 1 Donorojo Kabupaten Pacitan (Dani Eko). Perpustakaan sekolah menengah pertama Negeri 1 Donorojo dalam pengelolaan data administrasi perpustakaan masih banyak menemukan masalah yang 
http://e-journal.unipma.ac.id/index.php/doubleclick

bisa menghambat proses pelayanan kepada siswa-siswi.

2. Sistem informasi perpustakaan di SMP Negeri 2 Losari Kec. Losari Kab. Brebes (Ryan Septiana). SMP Negeri 2 Losari adalah sebuah sekolah tingkat menengah pertama negeri yang terletak di Jl. Bojongsari Kecamatan Losari Kabupaten Brebes. Pada saat sekarang ini, perpustakaan SMP Negeri 2 Losari Kab. Brebes masih menggunakan sistem manual yaitu pencatatan buku baru, data anggota, transaksi peminjaman dan pengembalian buku yang dicatat dalam buku besar diantaranya berisi data-data buku, data anggota, transaksi peminjaman dan pengembalian. Sistem ini sudah dianggap tidak efisien lagi mengingat pesatnya peningkatan jumlah buku.

3. Sistem informasi perpustakaan pada SMPN 1 Pejagoan (Fandy Sulsitiawan). di SMP 1 Pejagoan pengelolaan data perpustakaannya masih secara manual, sehingga akan menimbulkan masalah, mulai dari lamanya waktu yang diperlukan untuk mencatat data-data perpustakaan, mencatat tanggal peminjaman dan pengembalian, serta kegiatan lainnya. Hal ini menimbulkan terlambatnya pembuatan laporan yang berkaitan dengan lambatnya informasi, sehingga akan sulit untuk dijadikan acuan pengambilan keputusan atau tindakan yang diperlukan untuk kemajuan perpustakaan.

Dari ketiga referensi jurnal di atas dapat disimpulkan bahwa ketiga perpustakaan tersebut dalam pengelolaan data administrasi perpustakaan masih banyak menemukan permasalahan yang bisa menghambat proses pelayanan kepada siswa-siswi. Dengan masih ditemukan masalah dalam pengelolaan data administrasi pada perpustakaan Sekolah, khususnya di SMP, maka dibuatlah suatu perangkat lunak yang bisa memberi solusi untuk membantu petugas perpustakaan dalam mengelola data administrasi perpustakaan Sekolah Menengah Pertama Negeri 1 Madiun. Hasil penelitian ini dapat memberi solusi untuk meningkatkan pelayanan dan kinerja petugas perpustakaan dalam hal pengelolaan data administrasi perpustakaan serta mempercepat transaksi peminjaman dan pengembalian buku oleh siswa.

\section{Sistem}

Sistem adalah seperangkat elemen yang membentuk kumpulan atau prosedur prosedur/bagan-bagan pengolahan yang mencari suatu tujuan bagian atau tujuan bersama dengan mengoperasikan data dan/atau barang pada waktu rujukan tertentu untuk menghasilkan informasi dan/atau energi dan/atau barang (Murdick, 1991).

\section{Informasi}

Informasi adalah data yang diolah menjadi bentuk yang lebih berguna dan lebih berarti bagi yang menerimanya. Suatu informasi dikatakan bernilai bila manfaatnya lebih efektif dibandingkan dengan biaya untuk mendapatkannya. Sedangkan kualitas dari informasi tergantung dari tiga hal yaitu informasi harus akurat, tepat pada waktunya,dan relevan.

\section{Sistem informasi}

Sistem Informasi adalah kombinasi dari manusia, fasilitas atau alat teknologi, media, prosedur dan pengendalian yang bermaksud menata jaringan komunikasi yang penting, proses atas transaksitransaksi tertentu dan rutin, membantu manajemen dan pemakai intern dan ekstern dan menyediakan dasar pengambilan keputusan yang tepat. (Nash, 2003)

\section{Perpustakaan}

Perpustakaan diartikan sebuah ruangan atau gedung yang digunakan untuk menyimpan buku dan terbitan lainnya yang biasanya disimpan menurut tata susunan tertentu yang digunakan pembaca bukan untuk dijual (Sulistya, 1993).

\section{PHP}

PHP adalah bahasa server-side scripting yang menyatu dengan HTML untuk membuat halaman web yang dinamis. Maksud dari server-side scripting adalah sintaks dan perintah-perintah yang diberikan akan sepenuhnya akan dijalankan diserver tetapi disertakan 
pada dokumen HTML (Sunarfrihantono 2002).

\section{XAMPP}

XAMPP merupakan merupakan paket php berbasis open source yang dikembangkan oleh sebuah komunitas Open Source. Dengan menggunakan XAMPP kita tidak perlu lagi melakukan penginstalan program yang lain karena semua kebutuhan telah disediakan oleh XAMPP. Beberapa pakat yang telah disediakan adalah Apache, MySql, Php, Filezila, dan Phpmyadmin (Bunafit, 2013).

\section{MySQL}

MySQL adalah multiuser database yang menggunakan bahasa Structured Query Language (SQL). MySQL dalam operasi client server melibatkan server daemon MySQL disisi server dan berbagai macam program serta library yang berjalan disisi client. MySQL mampu mengangani data yang cukup besar. (Sunarfrihantono 2002).

Java

Java adalah bahasa pemrograman tingkat tinggi yang berorientasi objek dan program java tersusun dari bagian yang disebut kelas (Saputra, 2015)

\section{Netbeans}

Netbeans adalah sebuah aplikasi integrated development Environment (IDE) yang berbasiskan java dari sun microsystems yang berjalan di atas swing.

\section{METODE PENELITIAN}

Informasi yang digunakan untuk menganalisa permasalahan di perpustakaan SMPN 1 Madiun ini dapatkan dari melakukan penelitian dan wawancara salah satu seorang murid SMP setempat serta. Yang menginformasikan bahwa di perpustakaan SMP N 1 Madiun masih menggunakan buku besar dalam pengolahan data meminjam dan pengembalian buku.Langkah-langkah yang digunakan dalam model penelitian Perangkat lunak adalah mengumpulkan data dari sumber siswa smp. Model yang digunakan adalah model waterfaal.

\section{HASIL DAN PEMBAHASAN}

Analisa kebutuhan fungsional Dalam pembuatan sistem informasi ini diperlukan beberapa kebutuhan. Untuk kebutuhan fungsional sistem ini antara lain:

1. Siswa

Siswa lebih mudah mendapatkan informasi dalam meminjam dan mengembalian buku perpustakaan.

2. Petugas perpustakaan

Petugas memberikan informasi yang berkaitan dengan data peminjaman dan pengembalian buku.

Analisa Kebutuhan Non Fungsional Selain kebutuhan fungsional juga di perlukan kebutuhan non fungsional. Antara lain:

Kebutuhan perangkat lunak (software) PHP, MySQL, Java, Xampp, Neatbean

Kebutuhan perangkat keras (Hardware)

Tabel 1. Spesifikasi Hardware

\begin{tabular}{|l|l|}
\hline Prosesor & Intel pentium 4 \\
\hline Ram & $1 \mathrm{gb}$ \\
\hline Motherboard & P5g41tmlx 3 775 \\
\hline Harddisk & $80 \mathrm{gb}$ \\
\hline Optical drive & Dvd rw \\
\hline Monitor & 17 inch \\
\hline Perangkat input & $\begin{array}{l}\text { Keyboard \& } \\
\text { mouse }\end{array}$ \\
\hline
\end{tabular}

Kebutuhan Pengguna (Brainware)

Perancangan sistem informasi perpustakaan ini melibatkan beberapa pengguna, baik yang terlibat dalam pembuatan sistem, atau pada saat implementasi. Yang terlibat adalah:

1. Sistem analis adalah orang yang bertugas menganalisis sistem yang akan di buat.

2. Programmer adalah orang yang bertugas membuat program.

Kebutuhan Internal

Tabel 2. Analisis SWOT Kekuatan dan Kelemahan

\begin{tabular}{llr}
\hline Kekuatan & \multicolumn{2}{c}{ Kelemahan } \\
\hline Data-data yang & Jika & Hardware \\
di simpan lebih & atau & hardisk \\
akurat & rusak data akan \\
dibanding & hilang. & \\
menyimpan & & \\
data dengan & & \\
cara manual. & & \\
\hline
\end{tabular}




\section{Kebutuhan Ekstrenal}

Tabel 3. Analisis SWOT Peluang dan

Ancaman

\begin{tabular}{lrlr}
\hline Peluang & \multicolumn{2}{l}{ Ancaman } \\
\hline Dengan sistem & Smp lainnya \\
informasi yang & sudah & \\
baru menjadi & mempunyai \\
peluang bagi Smp & sistem informasi \\
negeri ini menjadi & memakai r web \\
lebih maju dalam & yang & sama \\
bidang & dengan r Smp \\
perpustakaan & Negeri 1 Madiun \\
\hline
\end{tabular}

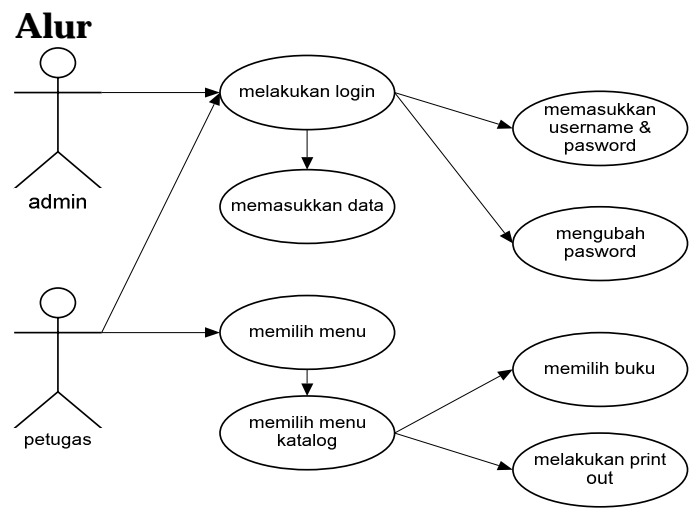

Gambar 1 User Case Diagram Power Designer

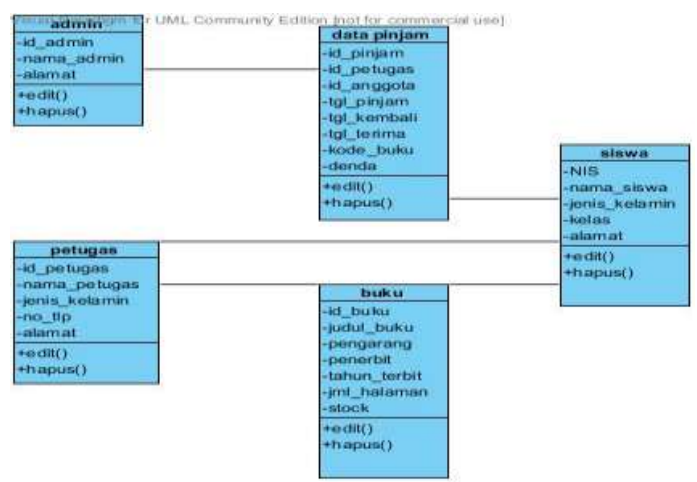

Gambar 2 Power Designer

Interface

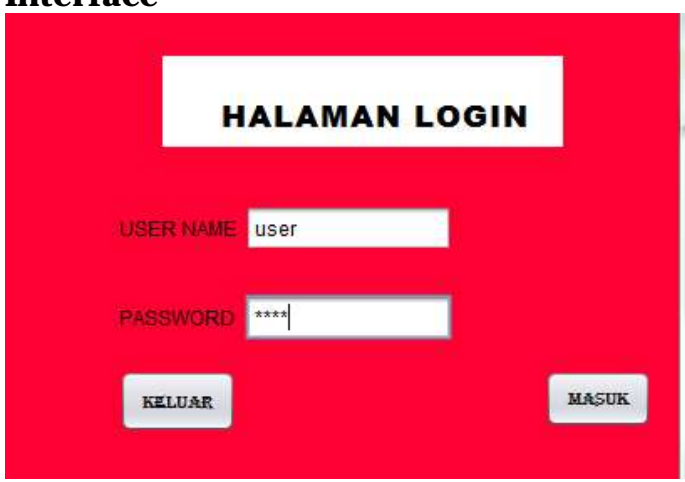

Gambar 3 Halaman Login Pengguna

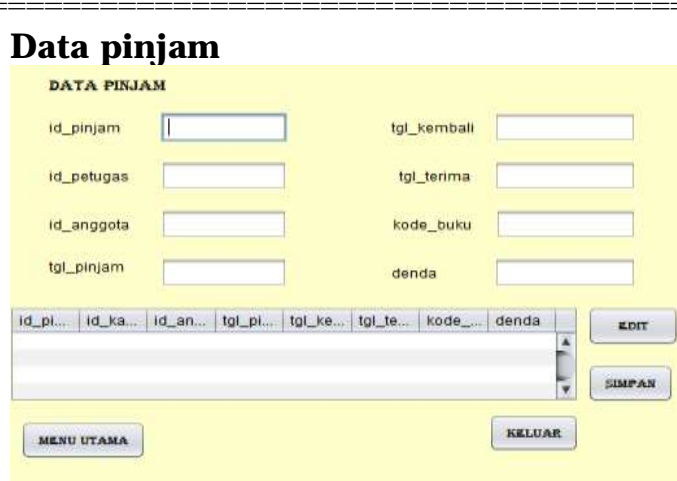

Gambar 4 Form Data Peminjam Data buku

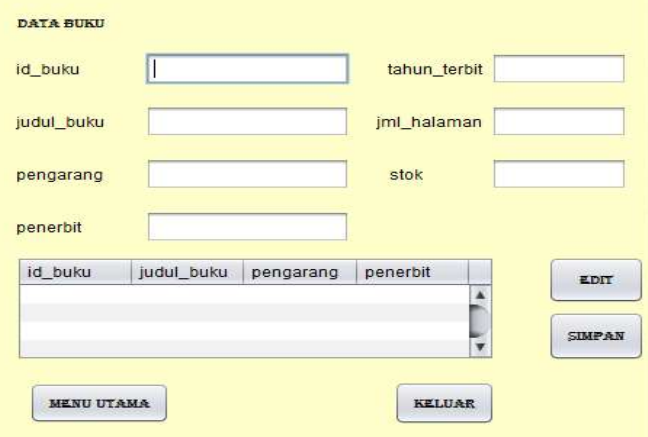

Gambar 4 Form Data Buku

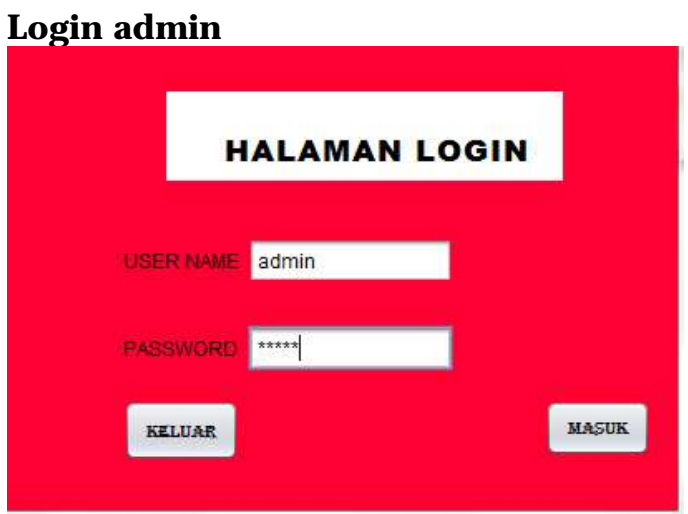

Gambar 3 Halaman Login Admin

Data admin

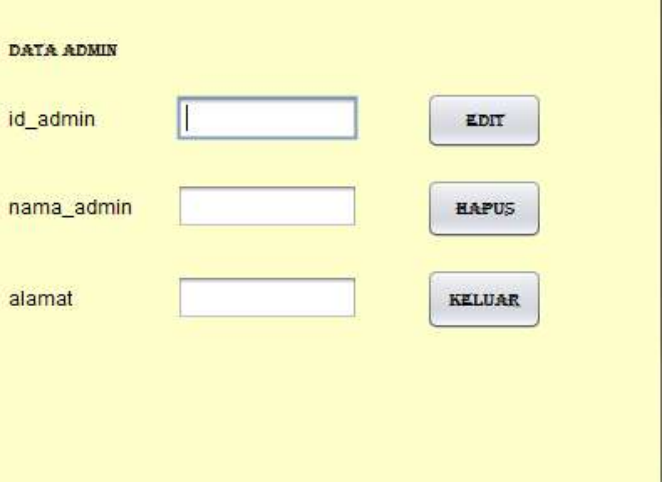

Gambar 4 Form Data Admin 
Data siswa

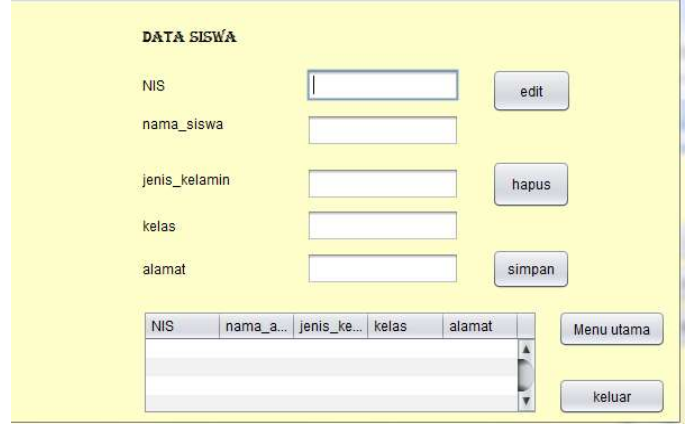

Gambar 5 Form Data Siswa

Implementasi

Pada sistem baru ini waktu yang diperlukan untuk menghasilkan rekap data siswa, rekap data buku, pembuatan kartu anggota, rekap buku dipinjam atau dikembalikan yang diperlukan dalam waktu-waktu tertentu dapat diberikan dalam waktu relatif singkat dibandingkan dengan sistem lama. Dan dibandingkan dengan sistem yang ada sekarang yang dibuat lebih praktis karena dapat langsung mencetak kartu anggota ketika anggota melakukan konfirmasi setelah mendaftar.

Selain itu, aplikasi ini akan memudahkan siswa dalam memantau ketersediaan buku yang ada di perpustakaan sekolah. Siswa akan diberikan kemudahan mencari daftar buku melalui aplikasi ini.

\section{Kesimpulan}

Berdasarkan pembahasan dan hasil yang diperoleh maka dapat disimpulkan bahwa Sistem Informasi Perpustakaan dapat memberikan kemudahan bagi pihak dalam lingkungan kerja dalam melaksanakan aktivitas dalam perpustakaan. Sistem ini terdiri dari file pokok anggota, file buku, file transaksi, file pengaturan, file stok serta peminjaman dan pengembalian buku.

Daftar Pustaka

Arif, I. 2003. Konsep dan perencanaan dalam otomasi perpustakaan. Makalah Seminar dan Workshop Sehari Membangun Jaringan Perpustakaan Digital dan Otomasi Perpustakaan Menuju Masyarakat Berbasis Pengetahuan.
Muhammadiyah Malang, 4 Oktober $2003.14 \mathrm{hlm}$.

http://duniaperpustakaan.com/2010/10 04/daftar-perpustakaanonline-di-seluruhindonesia/akses 16 Oktober 2011

Jogianto, H.M. 1995. Analisis dan Desain Sistem Informasi. Yogyakarta. Andi Publisher.

Kadir, Abdul. 2003. Pengenalan Sistem Informasi. Yogyakarta. Andi Publisher.

Murdick, Robert G dkk. 1991. Sistem Informasi Untuk Manajemen Modern. Jakarta: Erlangga

Nash, F. John, diterjemahkan oleh La Midjan. 2003. "Sistem Informasi Akuntansi I Pendekatan Manual Pratika Penyusunan Metode dan Prosedur". Bandung : Lembaga Informatika Akuntansi.

Nugroho, Bunafit. 2013. Dasar Pemograman Web PHP - MySQL dengan. Dreamweaver. Yogyakarta : Gava Media.

Saputra, Indra. 2015. Sistem Kendali Suhu, Kelembaban dan. Level Air pada Pertanian Pola Hidroponik. Jurnal Coding,. Sistem Komputer Untan Volume 03, No. 1 (2015), hal 1-10.

Sulistya Basuki. 1993. Pengantar IImu Perpustakaan. Universitas Terbuka

Sunarfrihantono, Bimo. 2002. PHP Dan MySQL Untuk Web. Yogyakarta: Andi. 